\title{
PENERAPAN MEDIA GAMBAR MNEMONIK, METODE RESITASI, DAN PERMAINAN KARTU HURUF UNTUK MENINGKATKAN PENGUASAAN HIRAGANA PADA SISWA KELAS XI IBB 1 DI SMA NEGERI 2 SINGARAJA TAHUN AJARAN 2018/2019
}

\author{
P. I. Apriantara ${ }^{1}$, K. E. K. Adnyani ${ }^{2}$, D. M. S. Mardani ${ }^{3}$ \\ ${ }^{123}$ Jurusan Pendidikan Bahasa Jepang, Universitas Pendidikan Ganesha, Singaraja \\ e-mail: apriantara.indra@undiksha.ac.id, krishna.adnyani@undiksha.ac.id, desak.mardani@undiksha.ac.id
}

\begin{abstract}
Abstrak
Penelitian ini bertujuan untuk (1) meningkatkan penguasaan huruf hiragana siswa melalui penerapan media gambar mnemonik, metode resitasi, dan permainan kartu huruf. (2) Mengetahui respons siswa terhadap penerapan media gambar mnemonik, metode resitasi, dan permainankartu huruf. Subjek dalam penelitian ini adalah siswa kelas XI IBB 1 SMA Negeri 2 Singaraja tahun ajaran 2018/2019 yang berjumlah 24 orang. Metode pengumpulan data yang digunakan pada penelitian ini adalah observasi, tes, kuesioner, dan wawancara. Data hasil penelitian dianalisis dengan menggunakan teknik analisis data deskriptif kuantitatif dan deskriptif kualitatif. Hasil penelitian menunjukkan bahwa (1) penerapan media gambar mnemonik, metode resitasi, dan permainan kartu huruf dapat meningkatkan penguasaan huruf hiragana siswa. Hal ini ditunjukkan dari peningkatan persentase ketuntasan klasikal yang terjadi pada hasil pre-test sebesar $4 \%$, kemudian pada siklus I meningkat menjadi $50 \%$, dan peningkatan yang drastis terjadi pada siklus II mencapai $96 \%$. (2) Respon siswa tergolong positif, hal tersebut dilihat dari rata-rata respon siswa pada siklus I yaitu 30 , sedangkan pada siklus II respons siswa diperoleh dengan rata-rata 34. Sehingga dapat disimpulkan bahwa penerapan media gambar mnemonik, metode resitasi, dan permainan kartu huruf dapat meningkatkan penguasaan huruf hiragana siswa dengan respons yang positif.
\end{abstract}

Kata kunci: Media Gambar Mnemonik, Metode Resitasi, Permainan Kartu Huruf

要旨

本研究の目的は (1) ニ一モニック画像メでイアと課題提出学習法と文字カードゲームの利用に より、ひらがなの習得力を高めるか、(2) ニ一モ婳像メでイアと課題提出学習法と文字 カードゲームの利用に対して、学習者の反応がどのようなことかを明らかにする。調査協力者 はシンガラジャ第二国立高等学校の二年生の 24 名である。調査方法は観察、テスト、アンケ 一ト、及びインタビューである。このデータを定量的及び定性的記述法により分析した。分析 した結果、(1) ニーモニック画像メでイアと課題提出学習法と文字カードゲームの利用により 、ひらがなの習得力を高める可能性がある。プレテストが4 ・ 、サイクル I でが50\%、サイ クルIIでが $96 \%$ 超えることが分かった。つまり、ひらがなの習得力を高めて続いているこが 言える。（2）学習者の反応において、サイクル Iにでの平均点数が30点であり、サイクル IIの平均が34点であったから、ひらがなの習得力を高めるのに利用されたニーモニック画 像メでイアと課題提出学習法と文字カードゲームに対する学習者の反応が良いという ことが分かった。

キーワード : ニーモニック、課題提出学習法、文字カードゲーム

\section{Pendahuluan}

Bahasa Jepang mengalami perjalanan yang sangat panjang, hingga akhirnya dimasukkan ke dalam kurikulum pendidikan Indonesia sebagai mata pelajaran dan menjadi program studi di perguruan tinggi. Sampai saat ini mata pelajaran bahasa Jepang tetap ada dan terus berkembang dalam kurikulum 2013. Kurikulum 2013 merupakan penerapan metode belajar siswa lebih aktif, kreatif dan inovatif dalam setiap pemecahan masalah yang dihadapi di sekolah. SMA Negeri 2 Singaraja merupakan salah satu contoh sekolah yang menerapkan 
kurikulum 2013 sejak dikeluarkannya kebijkan baru oleh Menteri Pendidikan pada tahun 2013.

Dilihat dari penerapan kurikulum 2013, seharusnya pembelajaran di kelas menjadi lebih kreatif dan inovatif serta mampu membuat siswa menjadi lebih aktif. Akan tetapi, tidak pada kelas XI IBB 1 di SMA Negeri 2 Singaraja pada tahun ajaran 2018/2019. Pembelajaran bahasa Jepang yang dilakukan menggunakan pendekatan teacher center. Teacher centered approach adalah suatu pendekatan belajar yang berdasar pada pandangan bahwa mengajar adalah menanamkan pengetahuan dan keterampilan (Smith, dalam Sanjaya, 2008). Dalam hal ini guru menjadi pusat peran dalam pencapaian hasil pembelajaran dan seakan-akan menjadi satu-satunya sumber ilmu. Hal tersebut dibuktikan pada lebih banyaknya guru melakukan kegiatan belajar mengajar dengan bentuk ceramah (lecturing), sehingga siswa sebatas memahami materi yang diajarkan sambil membuat catatan bagi mereka yang memerlukannya.

Pengajaran yang dilakukan oleh guru bahasa Jepang di SMA Negeri 2 Singaraja dapat dikatakan memberikan informasi satu arah, karena yang ingin dicapai adalah bagaimana guru bisa mengajar dengan baik sehingga yang terjadi hanya proses transfer pengetahuan. Melalui pendekatan yang diterapkan oleh guru tersebut, siswa menjadi takut untuk berpendapat dan akhirnya cenderung menjadi pelajaran yang pasif serta membuat kreativitas dari siswa menjadi menurun. Hal ini dapat dilihat selama proses pembelajaran bahasa Jepang berlangsung di kelas, dengan siswa hanya melakukan kegiatan mendengarkan dan mencatat apa yang guru tuliskan dipapan tulis, tanpa adanya interaksi tanya jawab yang dilakukan.

Selain dari kondisi kelas yang cenderung pasif, kemampuan siswa dalam menguasai huruf hiragana juga masih terbilang rendah. Hal ini dibuktikan dari hasil tes awal yang diberikan kepada 24 jumlah siswa kelas XI IBB 1 bahwa sebanyak 96\% siswa belum mampu menguasai huruf hiragana. Berdasarkan hasil wawancara dengan guru pengampu mata pelajaran bahasa Jepang, siswa akan difokuskan terlebih dulu pada pembelajaran bagian penguasaan huruf yaitu hiragana.

Seperti yang diketahui bahwa belajar bahasa asing yang dalam hal ini adalah bahasa Jepang merupakan sesuatu yang sangat kompleks karena pembelajar bahasa Jepang tidak hanya mempelajari budaya, pola kalimat, dan menghafal kosakatanya saja. Akan tetapi juga harus mampu menguasai huruf Jepang dari dasar. Bahasa Jepang memiliki empat jenis huruf yang berbeda bentuknya dan berbeda juga kegunaannya. Huruf dalam bahasa Jepang disebut moji termasuk didalamnya adalah huruf hiragana, katakana, kanji, dan romaji.

Kemampuan menguasai huruf Jepang merupakan kemampuan yang tidak mudah, mengingat rumitnya bentuk huruf dan banyaknya jumlah huruf yang harus dikuasai oleh siswa. Berdasarkan hasil wawancara, guru juga menyatakan bahwa huruf Jepang dan penulisannya merupakan salah satu kendala yang dihadapi siswa saat ini dalam mempelajari bahasa Jepang. Hal ini juga dibuktikan dari hasil wawancara kepada siswa bahwa siswa sulit untuk membedakan huruf hiragana yang hampir mirip satu sama lain, kemudian siswa juga jarang melatih kembali huruf hiragana yang sudah diberikan sebelumnya, dan siswa merasa bosan dengan pembelajaran yang diberikan sebelumnya.

Untuk menanggulangi kendala-kendala yang dialami siswa, maka perlu terapkan media, metode, atau teknik pembelajaran yang tepat dan menyenangkan, serta dapat menarik minat siswa. Sehingga dapat menimbulkan kesan yang mendalam bagi siswa dan siswa tidak mudah lupa dengan materi pelajaran yang sudah diberikan sebelumnya. Menyikapi hal tersebut, maka dilakukanlah pembelajaran dengan penerapan media gambar mnemonik, metode resitasi dan permainan kartu huruf. Penerapan metode ini berlandaskan dari penelitian yang sudah pernah dilakukan sebelumnya.

Penelitian terdahulu yang pernah dilakukan sebagai acuan dari penelitian ini yakni, penelitian tentang metode resitasi oleh Suarningsih (2018). Perbedaan penelitian terletak pada materi yang diajarkan yaitu penguasaan huruf katakana, perbedaan yang kedua terletak pada subjek penelitian. Sedangkan persamaannya adalah menggunakan Penelitian Tindakan Kelas (PTK) dan menerapkan metode resitasi. Adapun tujuan dari penelitian tindakan kelas ini adalah sebagai berikut. 
1. Untuk mengetahui penerapan media gambar mnemonik, metode resitasi, dan permainan kartu huruf dapat meningkatkan kemampuan menguasai huruf hiragana pada siswa kelas XI IBB 1 di SMA Negeri 2 Singaraja tahun ajaran 2018/2019.

2. Untuk mengetahui respons siswa terhadap penerapan media gambar mnemonik, metode resitasi, dan permainan kartu huruf dalam penguasaan huruf hiragana.

\section{Metode}

Untuk mengumpulkan data yang diperlukan dalam penelitian ini, digunakan metode observasi, tes, kuesioner, dan wawancara. Metode observasi dilakukan untuk mengamati dan mencatat secara langsung proses pembelajaran dari awal sampai akhir pembelajaran dengan menggunakan pedoman observasi kelas yang sudah dirancang sebelumnya. Metode observasi dilakukan untuk memperoleh data terkait dengan penelitian tindakan dan kendala yang terjadi dalam pembelajaran bahasa Jepang. Observasi dilakukan selama penelitian tindakan berlangsung yaitu sebanyak tiga kali pada tiap siklus. Langkah observasi ini perlu dilakukan guna mengetahui kekurangan dan kelebihan pada tahap pelaksanaan sebelumnya.

Metode tes adalah metode yang digunakan untuk mengetahui tingkat keberhasilan penelitian tindakan yang dilakukan. Sutedi (2009) berpendapat bahwa tes merupakan alat ukur yang biasanya digunakan untuk mengukur hasil belajar siswa setelah selesai satu satuan program pengajaran tertentu. Tes dalam penelitian ini menggunakan soal subjektif berupa soal-soal isian yaitu pada romawi I menyalin huruf romaji ke dalam huruf hiragana. Selanjutnya pada romawi II siswa diberikan tes menyalin kosakata bahasa Jepang dari huruf romaji ke dalam huruf hiragana.

Metode kuesioner (angket) adalah teknik pengumpulan data dengan menyerahkan atau mengirimkan daftar pertanyaan untuk diisi oleh responden. Kuesioner digunakan untuk mendapatkan data tentang respons siswa terhadap pembelajaran huruf hiragana melalui penerapan media gambar mnemonik, metode resitasi dan permainan kartu huruf. Penyebaran kuesioner dilakukan setelah berlangsungnya siklus.

Metode wawancara dilakukan untuk mengumpulkan data dengan cara melakukan tanya jawab kepada narasumber, terkait penelitian tindakan yang dilaksanakan. Metode wawancara yang dugunakan adalah metode semi struktural dengan menggunakan format pertanyaan dan alat perekam digital. Wawancara dilakukan dengan tujuan untuk mengetahui hal-hal yang kurang optimal selama proses pembelajaran. Wawancara dilakukan kepada guru dan 3 siswa yang memiliki kemampuan yang berbeda yaitu 1 siswa dengan nilai tinggi, 1 siswa dengan nilai sedang, dan 1 siswa dengan nilai rendah. Pelaksanaan wawancara dilakukan setelah berlangsungnya siklus.

Data dianalisis setelah data terkumpul. Ada dua jenis data yang digunakan pada penelitian ini, yaitu data kuantitatif dan data kualitatif. Analisis data kuantitatif adalah penyajian data dengan menggunakan angka-angka atau berdasarkan data statistik, sedangkan analisis data kualitatif adalah teknik penyajian data secara objektif berdasarkan data alami yang ditemukan di lapangan. Data kuantitatif diambil dari pre-test dan post-test. Sedangkan data kualitatif diambil dari hasil observasi dan kuesioner.

Melalui data kuantitatif dapat mencari nilai rata-rata, ketuntasan klasikal dan mengetahui peningkatan yang terjadi setelah diterapkannya media gambar mnemonik, metode resitasi dan permainan kartu huruf pada penguasaan huruf hiragana. Adapun langkah-langkah yang digunakan adalah dengan cara membandingkan hasil dari pre-test dengan post-test satu, post-test satu dengan post-test dua dan seterusnya. Sedangkan untuk mengetahui kestabilan respons siswa, data kualitatif juga perlu dilakukan perbandingan.

\section{Hasil dan Pembahasan}

Pada bagian ini akan disajikan data-data hasil penelitian terhadap peningkatan hasil belajar siswa kelas XI IBB 1 SMA Negeri 2 Singaraja dalam pembelajaran huruf hiragana. Hasil penelitian diuraikan dalam bentuk tahapan yang terdiri dari siklus-siklus pembelajaran yang dilakukan dalam proses belajar mengajar di kelas. Data diperoleh dari instrumen 
penelitian sesuai dengan prosedur penelitian yang telah dirancang sebelumnya. Data tersebut merupakan hasil pengamatan (observasi), tes, kuesioner, dan wawancara mangenai penerapan media gambar mnemonik, metode resitasi dan permainan kartu huruf. Adapun hasil dan pembahasan pada penelitian ini adalah sebagai berikut.

\section{Kondisi Awal}

Observasi awal dalam penelitian tindakan dilakukan untuk mengetahui kondisi awal siswa dalam menerima pembelajaran bahasa Jepang sebelum penelitian tindakan kelas dilakukan dengan penerapan media gambar mnemonik, metode resitasi, dan permainan kartu huruf.

Selain melakukan observasi awal tentang kondisi siswa, diperlukan suatu langkah awal untuk mengetahui secara pasti kemampuan siswa dalam penguasaan huruf hiragana yaitu melalui tes awal (pre-test). Tujuan dari pemberian pre-test adalah untuk mengetahui kemampuan awal siswa terhadap penguasaan hurus hiragana.

Hasil yang diperoleh dari observasi awal adalah metode pembelajaran yang digunakan oleh guru pada saat mengajar yaitu menggunakan metode ceramah. Kendala yang ditemukan dalam proses pembelajaran huruf hiragana yaitu siswa terlihat kurang fokus terhadap pelajaran, serta siswa kurang aktif dalam bertanya maupun menjawab pertanyaan. Sehingga setelah diberikan tes awal, sebagian besar hasil belajar siswa belum mencapai KKM yang telah ditentukan oleh sekolah. Hal ini dapat dilihat dari hasil yang diperoleh 24 jumlah siswa kelas XI IBB 1 SMA Negeri 2 Singaraja, hanya 1 siswa (4\%) yang mampu mencapai/melebihi KKM dan 23 siswa lainnya belum mampu mencapai KKM. Dari keterangan tersebut dapat ditarik kesimpulan bahwa hasil belajar siswa kelas XI IBB 1 SMA Negeri 2 Singaraja pada mata pelajaran bahasa Jepang tentang huruf hiragana masih terbilang rendah.

Melihat dari hasil awal tersbut maka, penelitian tindakan dapat dilanjutkan ketahap selanjutnya yaitu pelaksanaan siklus dengan penerapan media gambar mnemonik, metode resitasi, dan permainan kartu huruf untuk meningkatkan penguasaan huruf hiragana pada siswa kelas XI IBB 1.

\section{Hasil Penelitian Siklus I}

Untuk mengetahui hasil belajar siswa selama tiga kali pertemuan dalam pelaksanaan siklus I maka dilakukan post-test I pada Senin, 4 Februari 2019. Soal yang diberikan pada post-tes I berkaitan dengan materi yang sebelumnya dipelajari pada pertemuan pertama, kedua, dan ketiga dalam siklus I. Hasil belajar yang diperoleh siswa pada siklus I dapat dinyatakan mengalami peningkatan dari pre-test sebelumnya. Hal ini dilihat dari 24 jumlah siswa (100\%) kelas XI IBB 1 SMA Negeri 2 Singaraja yang memenuhi KKM pada post-test I sebanyak 12 orang (50\%). Pemerolehan nilai tertinggi yaitu 98 sedangkan nilai terendah yaitu 22. Dengan rata-rata nilai hasil post-test I keseluruhan siswa kelas XI IBB 1 adalah 61.

Berdasarkan kriteria keberhasilan yang dipaparkan sebelumnya, apabila $75 \%$ dari jumlah siswa yang memeroleh nilai 68 ke atas (KKM) maka penelitian atau tindakan dapat dihentikan. Akan tetapi dari hasil post-test siklus I belum mencapai $75 \%$. Sehingga penelitian tindakan masih akan dilanjutkan ke siklus II untuk meningkatkan penguasaan huruf hiragana siswa kelas XI IBB 1 melalui penerapan media gambar mnemonik, metode resitasi, dan permainan kartu huruf.

\section{Hasil Penelitian Siklus II}

Hasil belajar siswa pada siklus II mengalami peningkatan yang drastis dibandingkan dengan hasil pre-test dan post-test yang telah dilakukan sebelumnya. Dari 24 jumlah siswa (100\%) kelas XI IBB 1 SMA Negeri 2 Singaraja yang memenuhi KKM pada post-test II sebanyak 23 orang (96\%). Adapun pemerolehan nilai tertinggi yaitu 100 sedangkan nilai terendah yaitu 51. Rata-rata nilai hasil post-test II siswa kelas XI IBB 1 adalah 84 . Berdasarkan kriteria keberhasilan yang dipaparkan sebelumnya, apabila $75 \%$ dari jumlah siswa yang memeroleh nilai 68 ke atas (KKM) maka penelitian tindakan dapat dihentikan. Melihat ketuntasan klasikal post-test II yang telah mencapai angka $96 \%$, penelitian ini dapat dihentikan karena telah melampaui kriteria ketuntasan minimal yang tersedia.

\section{Pembahasan}

Berdasarkan temuan penelitian yang dilakukan di kelas XI IBB 1 SMA Negeri 2 Singaraja 
pada mata pelajaran bahasa Jepang, terlihat siswa telah mengalami peningkatan penguasaan huruf hiragana secara bertahap dan juga drastis. Hal tersebut dibuktikan pada hasil belajar siswa yang mengalami peningkatan dari siklus I sampai dengan siklus II setelah dilakukan penelitian tindakan pada kelas tersebut dengan penerapan media gambar mnemonik, metode resitasi, dan permainan kartu huruf.

Tercapainya suatu keberhasilan dalam proses pembelajaran disebabkan dari berbagai persiapan sebelum dilakukannya penelitian tindakan seperti, menyiapkan instrumen penelitian, menentukan waktu pelaksanaan tindakan, melakukan bimbingan dengan guru pamong sebelum mengajar, menyusun RPP, membuat skenario pembelajaran, mengikuti langkah-langkah penerapan media gambar mnemonik, metode resitasi, dan permainan kartu huruf, serta menyediakan perlengkapan lain sebagai sarana pendukung kelancaran proses pembelajaran yang tidak terlepas dari tujuan pembelajaran.

Selain dari persiapan yang direncanakan, faktor keberhasilan penelitian tindakan juga disebabkan dari pemilihan metode pembelajaran dan strategi pembelajaran yang tepat sesuai karakteristik atau permasalahan yang terjadi di kelas. Pemilihan metode pembelajaran dan strategi pembelajaran sangat penting dilakukan sesuai dengan kebutuhan siswa agar tercapainya tujuan dari pembelajaran yang diharapkan. Dengan demikian, terlebih dulu dilakukan observasi awal, wawancara, dan pemberian tes awal kepada narasumber yang bersangkutan guna mengetahui karakteristik dan permasalahan yang dihadapi siswa.

Permasalahan yang dihadapi siswa adalah penguasaan huruf hiragana yang masih rendah. Adapun beberapa faktor yang menyebabkan hal tersebut yaitu, siswa jarang melatih kembali huruf hiragana yang sudah dipelajari, siswa kesulitan membedakan beberapa huruf hiragana yang hampir mirip satu sama lain, media pembelajaran yang digunakan guru membuat siswa bosan dan ditambah lagi dengan karakteristik siswa yang tidak aktif membuat kelas cenderung pasif. Maka diterapkanlah media gambar mnemonik, metode resitasi, dan permainan kartu huruf untuk dapat memberikan penanggulangan berdasarkan permasalahan dan karakteristik yang dialami siswa.

Berdasarkan hasil belajar yang diperoleh melalui penerapan media gambar mnemonik, metode resitasi, dan permainan kartu huruf dalam meningkatkan penguasaan hiragana pada siswa kelas XI IBB 1 di SMA Negeri 2 Singaraja telah memenuhi kriteria keberhasilan yang berlandaskan pada KKM. Hal ini dapat dibuktikan dari hasil yang telah diperoleh pada siswa dengan rata-rata yang diperoleh pada siklus I adalah 61 dengan ketuntasan klasikal mencapai $50 \%$, sedangkan rara-rata yang diperoleh pada siklus II adalah 85 dengan ketuntasan klasikal mencapai $96 \%$.

Selanjutnya penyebaran kuesioner juga diberikan kepada seluruh siswa kelas XI IBB 1. Setiap kuesioner tediri dari 7 pernyataan kuesioner tertutup dan 3 pertanyaan kuesioner terbuka. Rata-rata yang diperoleh pada kuesioner siklus I adalah 30 , sedangkan rata-rata pada kuesioner siklus II yang diperoleh menjadi 34. Respons siswa kelas XI IBB 1 dapat dikatakan meningkat dan tergolong positif, hal ini sebanding dengan penelitian yang dilakukan oleh Agustin (2017) yang menunjukkan bahwa adanya peningkatan respons siswa terhadap perubahan yang dilakukan dengan rata-rata respons siswa pada siklus I yaitu 36,5 yang tergolong positif, dan respons siswa pada siklus II menjadi 40,4 juga tergolong positif. Setelah tes dan kuesioner diberikan, selanjutnya dilakukan wawancara kepada siswa.

Wawancara juga telah dilakukan kepada tiga siswa yang memiliki kemampuan berbeda diantaranya, satu siswa dengan kemampuan tinggi, satu siswa dengan kemampuan sedang, dan satu siswa dengan kemampuan rendah. Dari hasil wawancara yang dilakukan pada siklus I dan siklus II siswa merasa berkesan, karena melalui penerapan media gambar mnemonik, metode resitasi, dan permainan kartu huruf kemampuan siswa terus dilatih sehingga membuat siswa semakin bisa dan cepat menghafal huruf hiragana. Siswa juga mengatakan lebih suka dengan pembelajaran yang seperti ini. Pada penerapan ini siswa juga mengalami peningkatan dalam kemampuan menguasai huruf hiragana, mulai dari siswa tidak bisa membaca, menulis, dan menghafal huruf hiragana, sekarang menjadi bisa. Selain itu siswa senang jika diberikan soal latihan disetiap pertemuan, karena dengan latihan soal yang terus dilakukan membuat siswa cepat dalam menghafal huruf hiragana. Dalam hal ini siswa juga menyatakan latihan soal yang diberikan disetiap pertemuan sangat bagus dilakukan, karena bertujuan mengasah kemampuan siswa. 
Pada penelitian ini seluruh siswa kelas XI IBB 1 telah mengalami peningkatan penguasaan huruf hiragana. Hal ini dapat dilihat pada keterangan perbandingan hasil pretest, post-test I dengan post-test II. Jadi, dapat disimpulkan bahwa penerapan media gambar mnemonik, metode resitasi, dan permainan kartu huruf dapat meningkatkan penguasaan huruf hiragana pada siswa kelas XI IBB 1 di SMA Negeri 2 Singaraja tahun ajaran 2018/2019.

\section{Simpulan dan Saran}

Berdasarkan pada hasil penelitian dan pembahasan, maka simpulan dari penelitian ini adalah:

(1) Penerapan media gambar mnemonik, metode resitasi, dan permainan kartu huruf dapat meningkatkan penguasaan huruf hiragana pada siswa kelas XI IBB 1 SMA Negeri 2 Singaraja. Peningkatan tersebut terbukti pada hasil belajar siswa dari rata-rata nilai yang diperoleh pada pretest yaitu 13 dengan ketuntasan klasikal 4\%, kemudian pada post-test I terjadi peningkat dengan perolehan rata-rata 61 dan ketuntasan klasikal yang diperoleh yaitu $50 \%$, selanjutnya peningkatan kembali terjadi pada siklus II dengan perolehan ratarata sebesar 85 dan ketuntasan klasikal yang diperoleh sebesar $96 \%$.

(2) Respons siswa kelas XI IBB 1 SMA Negeri 2 Singaraja terhadap penerapan media gambar mnemonik, metode resitasi, dan permainan kartu huruf untuk meningkatkan penguasaan huruf hiragana tergolong positif. Dari hasil kuesioner tertutup yang dilakukan pada siklus I diperoleh rata-rata skor yaitu 31, sedangkan hasil kuesioner tertutup yang dilakukan pada siklus II diperoleh rata-rata skor sebesar 34. Selain itu, dengan penerapan media gambar mnemonik, metode resitasi, dan permainan kartu huruf membuat siswa menjadi lebih percaya diri untuk menjawab tes maupun soal-soal latihan, meningkatkan daya ingat siswa terhadap materi yang sudah dipelajari, dan siswa menjadi aktif pada saat mengikuti proses pembelajaran.

Adapun saran untuk penelitian ini antara lain:

(1) Penelitian ini diharapkan dapat membantu guru dalam menemukan solusi dari permasalahan yang dialami siswa kelas XI IBB 1 di SMA Negeri 2 Singaraja untuk meningkatkan penguasaan huruf hiragana tahun ajaran 2018/2019. Dari penelitian ini juga diharapkan guru menerapkan pembelajaran yang menyenangkan dan dapat menarik minat siswa serta sesuai dengan karakteristik atau permasalahan yang dihadapi siswa dikemudian hari.

(2) Hasil penelitian ini dapat digunakan sebagai acuan bagi peneliti lain apabila hendak melakukan penelitian sejenis sesuai dengan penerapan media gambar mnemonik, metode resitasi, dan permainan kartu huruf pada mata pelajaran bahasa Jepang atau mata pelajaran lainnya. Pada penelitian ini masih perlu adanya perhatian pada hambatanhambatan yang terjadi, diharapkan pada penelitian yang akan dilakukan selanjutnya dapat diperbaiki dan lebih disempurnakan.

\section{Daftar Pustaka}

Agustin, I. P. A. 2017. Penerapan Model Pembelajaran Kooperatif Tipe Team-Assited Individualization (TAI) Berbantuan Media Kartu Tanketsu untuk Meningkatkan Kemampuan Mengingat Kosakata Bahasa Jepang Kelas XI IPB 1 di SMA Negeri 1 Sawan Tahun Ajaran 2016/2017. Skripsi (tidak diterbitkan). Jurusan Pendidikan Bahasa Jepang, Undiksha Singaraja.

Arsyad, Azhar. 2011. Media Pembelajaran. Jakarta: Rajawali Pers.

Atkinson, R. C., dan Raugh, M. R. 1975. An Application of The Mnemonic Keyword Method to The Acquisition of Rusian Vocabulary. Journal of Experimental Psychology: Human Learning and Memory, 104(2), 126133. 
Bjoerner, T. \& Hansen, C.B.S. 2010. Designing an Educational Game: Design Principles from a Holistic Persspective. The Journal International of Learning. 17 (2010), 279 - 288.

Chaplin, James P. 2011. Kamus Lengkap Psikologi. Jakarta: PT Raja Grafindo Persada.

Djamarah, Syaiful Bahri dan Zain, Azwan. 2006. Strategi Belajar Mengajar, Jakarta: Rineka Cipta, edisi revisi.

Komaidi, dkk. 2011. Panduan Lengkap PTK (Penelitian Tindakan Kelas) Teori, Praktek dan Contoh PTK. Cetakan Pertama. Yogyakarta: Sadba Media.

Maesaroh, Siti. 2013. Peranan Metode Pembelajaran Terhadap Minat dan Prestasi Belajar Pendidikan Agama Islam. Kependidikan, Volume 1, Nomor 1, Edisi Nopember 2013 (hal. 150-168).

Muhammad, As'adi. 2009. Menghidupkan Otak Kanan Anak Anda. Yogyakarta : Power Books.

Mujib, F. \& Rahmawati, N. 2011. Metode Permainan-permainan Edukatif dalam Belajar Bahasa Arab. Jogjakarta : Diva Press.

Rahmatia, Baiq Winda. 2018. Penerapan Metode Mnemonik Berbantuan Media Gambar untuk Meningkatkan Hasil Belajar Siswa pada Mata Pelajaran IPA Kelas IV SDN 42 Mataram Tahun 2017/2018. Skripsi (tidak diterbitkan). Mataram. Universitas Mataram.

Rohman, Arif Nur. dkk. 2013. Peningkatan Keterampilan Membaca dan Menulis Aksara Jawa Melalui Permainan Kartu Huruf. Volume 2, Nomor 2 (2014).

Sanjaya, Wina. 2008. Perencanaan dan desain sistem pembelajaran. Jakarta: Kencana Prenada Media Group.

Supriyono, Agus. 2009. Jenis-jenis Model Pembelajaran. Yogyakarta : Pustaka Belajar.

Suarningsih, Ni Kadek. 2018. Penggunaan Strategi Pembelajaran Ekspositori Berbantuan Metode Resitasi untuk Meningkatkan Penguasaan Huruf Katakana Siswa Kelas XI IPB SMAN 1 Sukasada Tahun Ajaran 2017/2018. Skripsi (tidak diterbitkan). Singaraja. Universitas Pendidikan Ganesha.

Sutedi, Dedi. 2009. Penelitian Pendidikan Bahasa Jepang. Bandung: Humanora.

Syaiful, Bahri. Aswin, Zain. 2006. Strategi Belajar Mengajar. Jakarta: PT Rineka Cipta.

Syarifuddin, Ahmad. 2011. "Belajar dan Faktor-Faktor yang Mempengaruhi". Penerapan Model Pembelajaran Cooperative, Volume XVI, Nomor 01, Edisi Juni 2011 (hlm. 113136).

Uno, Hamzah B. 2009. Teori Motivasi dan Pengukurannya (Analisis di Bidang Pendidikan). Jakarta: Bumi Aksara. 